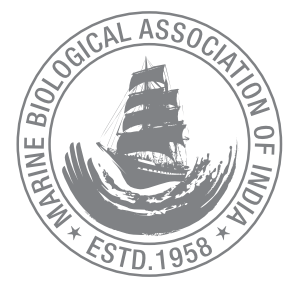

\title{
Observations on the biology of smooth dwarf monocle bream, Parascolopsis aspinosa (Rao \& Rao, 1981) from Mangaluru, southwest coast of India
}

\author{
Radhika Balachandran ${ }^{*}$, G. B. Purushottama ${ }^{2}$, P. U. Zacharia ${ }^{3}$ and Mansing Naik ${ }^{4}$ \\ ${ }^{1}$ Kerala University of Fisheries and Ocean Studies, Kochi - 682 506, Kerala, India. \\ ${ }^{2}$ Regional Centre of ICAR-CMFRI, Mangaluru - 575 001, Karnataka, India. \\ ${ }^{3}$ ICAR- Central Marine Fisheries Research Institute, Kochi - 682 018, Kerala, India. \\ ${ }^{4}$ College of Fisheries, Mangaluru - 575 002, Karnataka, India. \\ *Correspondence e-mail: radhikabalachandran7@gmail.com
}

Received: 10 June 2020 Accepted: 18 Sep 2020 Published: 25 Sep 2020

Original Article

\begin{abstract}
Some aspects of biological information is presented here for the little known smooth dwarf monocle bream, Parascolopsis aspinosa (Rao and Rao, 1981) (Perciformes: Nemipteridae) based on specimens collected from the bycatch of commercial shrimp trawlers operating in the Arabian Sea off the Karnataka coast. Eight-hundred forty seven specimens measuring 7.4 to $22.8 \mathrm{~cm} \mathrm{TL}$, and weighing between $15.0-216 \mathrm{~g}$ total weight were analysed for the study. The lengthweight relationships were found to be significantly different between the sexes $(P<0.001)$. The coefficients ' $a$ ', ' $b$ ' of the length-weight relationship were estimated as $0.0333,2.7919\left(r^{2}=0.961\right)$ for females and $0.0194,2.9791\left(r^{2}=0.962\right)$ for males and the species follows a negative allometric growth pattern $(b<3)$. The fish attains maturity $\left(\mathrm{TL}_{50}\right.$ ) at $12.5 \mathrm{~cm}$ TL for females and $11.5 \mathrm{~cm}$ TL for males. $P$. aspinosa was found to breed throughout the year with peak spawning during August-September and January. The overall sex ratio (M:F) favoured females at the rate of 1:1.15. A seven-stage maturity was found and a progressive increase in the size of the ova was traced to advanced stages of maturity. The total fecundity of P. aspinosa ranged from $45,823(12.3 \mathrm{~cm} \mathrm{TL} ; 41 \mathrm{~g}$ body weight) to 1,56,308 (22.8 cm TL; $216 \mathrm{~g}$ body weight) with an average fecundity of 84,367 eggs. Analysis of the stomach contents (\%IRI) revealed that $P$. aspinosa mainly fed on Saurida tumbil $(\%|R|=18.2)$, followed by Penaeus indicus (\%IRI=16.7), Loligo spp. $(\%|R|=15.2)$,
\end{abstract}

Squilla $(\%|R|=6.4)$, and Acetes spp $(\%|R|=2.7)$. Other detailed biological observations such as the length composition, sex ratio, and length at maturity $\left(\mathrm{TL}_{50}\right)$ of $P$. aspinosa are also provided in the study. Since the species has been poorly studied and assessed as Least Concern (LC) in the IUCN red list criterion, it is expected that the biological information from the present study will support the ongoing data generation and help in arriving at management decisions for the species in the future.

Keywords: Nemipteridae, Smooth dwarf monocle bream, diet, lengthweight relationship, length at maturity, fecundity

\section{Introduction}

Karnataka state along the eastern Arabian Sea of the southwest coast of India is very progressive in terms of adopting new fishing methods and now stands third in terms of all Indian marine fish production (CMFRI, 2017). Trawl fishing which is the mainstay of the states marine landing is now predominantly carried out beyond the shelf waters (Dineshbabu et al., 2017). As a consequence, demersal resources became the vital component in the marine fish catches in Karnataka with an estimate of $1,85,547$ tonnes ( $t$ ) forming $35 \%$ of the total catch (CMFRI, 2017). 
Among demersals, threadfin breams belonging to the family Nemipteridae has emerged as one of the important resource after mackerel and oil sardine in the State (CMFRI annual report, 2017-18). The family Nemipteridae comprise 5 genera and 67 species of tropical and sub-tropical Indo-West Pacific nemipterids (Russell, 1990) and Parascolopsis (monocle breams) is one among the five genera under this family. The genus can be identified from other nemipterids by the posterior margin of sub-orbital spine weak or absent; no canine teeth on jaws; 4-6 transverse scales on preopercle; second anal spine longer and robust than third spine.

Parascolopsis aspinosa (Rao and Rao, 1981) or Smooth dwarf monocle is one of the important species among the genus Parascolopis and is occasionally found along with the landing of threadfin breams by multi-day trawlers, though, in very small quantities. Nemipterids are locally known as "madhumal" in Karnataka. P. aspinosa can be distinguished from other Parascolopsis species with a black blotch between 7-10 spines, posterior margin of suborbital smooth or few tiny spines. $P$. aspinosa occurs in the deeper shelf to continental waters, at depths between 20-410 m (and up to $500 \mathrm{~m}$ ), in the Indo-West Pacific (from Persian Sea and Arabian Gulf to Australia and Japan) (Russell and Golani, 1993). The fish is reported from the Indian Ocean including the Persian Gulf; Gulf of Oman, Gulf of Aden, Arabian Sea, Bay of Bengal and the Andaman Sea. Though no major fishery exists for any species of Parascolopsis, small catches are taken off the southwest coast of India from trawlers (Radhika pers. observ.). Several studies have been carried out to understand the biology and life-history traits of nemipterid fishes (Zacharia and Nataraja, 2003; Manojkumar, 2004; Joshi, 2005; Kerdgari et al., 2009; Nettely et al., 2016), whereas the only study available on biology of any species of Parascolopsis from Indian waters is of Naik (2000) from Goan waters. Other than this work no information is available on fishery or any aspects of the biology of the species from other parts of the country because of the erratic and low volume of landings.

The present investigation, therefore, is aimed to provide preliminary information of $P$. aspinosa on its life history traits such as length composition, length-weight relationship, reproduction and spawning, and diet characteristics based on specimens collected from commercial trawlers operating along the Mangaluru coast, southwest coast of India, off the north eastern Arabian Sea.

\section{Material and methods}

A total of 827 specimens (females, 443; males, 384) were collected from trawl net landings at Mangaluru $\left(12^{\circ} 51^{\prime}\right.$ $10.8^{\prime \prime} \mathrm{N}, 74^{\circ} 49^{\prime} 58.8^{\prime \prime}$ E) fisheries harbour in Karnataka coast (Fig.1) during August 2017 to May 2018. The fishing operations were done in depth range between 30 and $200 \mathrm{~m}$ off the eastern Arabian Sea. The fishes were preserved in ice and brought to the laboratory in plastic boxes. The total length (TL) of each specimen was measured to the nearest $\mathrm{mm}$, and the total body weight (TW) to the nearest $g$ and its sex was recorded. The gonads were weighed to nearest $0.001 \mathrm{~g}$ using a digital balance. The length frequency distributions for each sex were tested to see if data conformed to a normal distribution using Shapiro-Wilk test (Shapiro and Wilk, 1965). Dependent on whether the data were distributed normally or not, inter-gender size differences were then investigated using a two-tailed $t$-test, to ascertain any sex-based differences in landings. Length frequency distribution of females and males was compared using the ms (Chi-square symbol $\chi^{2}$ ) test with the length distribution divided into $1.0 \mathrm{~cm}$ length class intervals of TL (Cochran, 1952). Sex-ratio was analysed by Chi-square $\left(\chi^{2}\right)$ test to determine for any significant deviation from 1:1 (Snedecor and Cochran, 1967). The parameters ' $a$ ' and ' $b$ ' of the length-weight relationships were estimated using the equation proposed by Le Cren (1951): $W=a^{*} L^{b}$. After logarithmic transformation of the length and weight data, this equation may be expressed as: $\log \mathrm{TW}=\log a+$ $b^{*} \log \mathrm{TL}$, where TW is the weight of the fish in $\mathrm{g}$ and TL is the total length of the fish in $\mathrm{cm}$; ' $a$ ' is the intercept of the regression curve (coefficient related to body form) and ' $b$ ' is the regression coefficient (exponent indicating isometric growth; Froese, 2006). The confidence and prediction intervals were calculated for the length and weight of the fish in the LWR using the following formulae: the confidence interval for the mean response when predictor is $x^{*}$ is $\hat{y} \pm t^{*} S \in \sqrt{ } 1 / n+\left(x^{*}-x\right)^{2}$ $/(\mathrm{n}-1) s^{2}$ and the prediction interval for an individual response when the predictor is $x^{*}$ is $\hat{y} \pm t * S \in \sqrt{ } 1+1 / n+\left(x^{*}-x\right)^{2} /(n-1) s^{2} x$

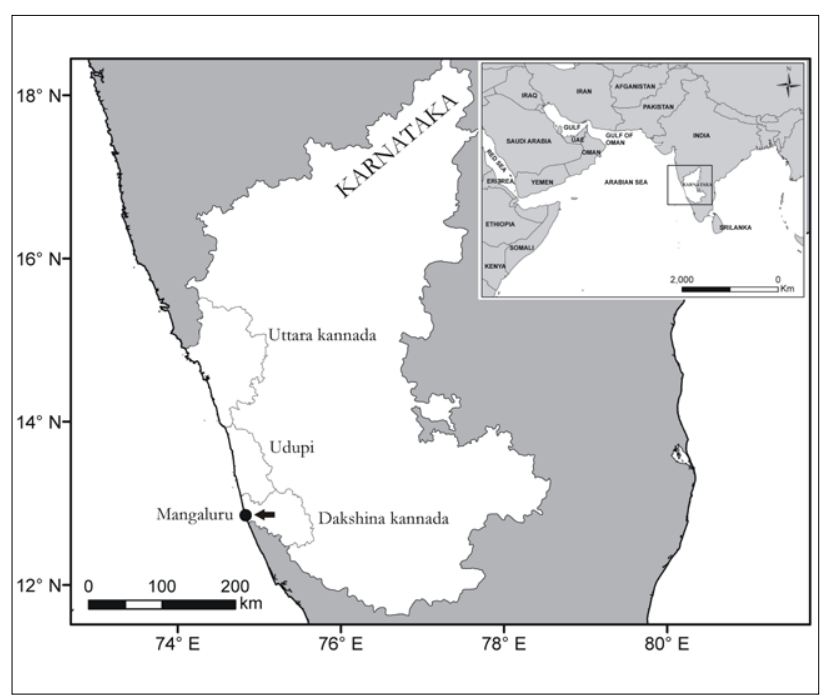

Fig. 1. Map showing Mangaluru fish landing centre, Karnataka, the location from where $P$. aspinosa was collected. 
(Montgomery et al., 2012). The male and female length-weight relationship was tested for significant difference using the extra sum of squares method involving full and reduced regression models for testing the common slope (parallel lines), while the $F$-statistic was computed to test the difference between the two slopes (Montgomery et al., 2012).

Maturity stages in females were classified based on the macroscopic appearance of the ovary following ICES scale (Lovern and Wood, 1937) with appropriate modifications, and microscopic characteristics of ova preserved in $10 \%$ neutral buffered formalin. For studying the growth of ova, 600 intraovarian egg diameter were measured by taking out small pieces of ovaries from the anterior, middle and posterior regions and the ova teased out on to a glass slide. Intra-ovarian egg diameter was measured by calibrated ocular micrometer with a magnification of $0.016 \mathrm{~mm}$ to each ocular micrometer division (O.M.D), which was mounted on the eyepiece of a compound microscope.

Spawning periodicity was estimated from the percentage occurrence of mature ovaries and gonadosomatic index (GSI) during the study period. Individuals with stage III and above were considered as mature. GSI value was calculated following Ellis and Shackley (1997) and tested for statistical significance following Snedecor and Cochran (1967). Fecundity of the fish and correlation analysis for fecundity and total length, body weight and gonad weight of $P$. aspinosa were estimated following Manojkumar (2004).

The $\mathrm{TL}_{50}$ for females and males were derived from the following logistic regression, where the proportion, $\mathrm{pL}$, of the fishes that were mature at TL was calculated as: $\mathrm{pL}=$ $\left\{1+\mathrm{e}^{\left[-\ln (19)\left(\mathrm{TL}-\mathrm{TL}_{50}\right)\left(\mathrm{TL}_{95}{ }^{-} \mathrm{TL}_{50}\right)\right]-1}\right\}^{-1}$, where $\mathrm{TL}_{50}$ and $\mathrm{TL}_{95}$ are constants and ' $I n$ ' is the natural logarithm. Maximum likelihood estimates of the parameters were obtained using the routine SOLVER in Microsoft ${ }^{\mathrm{TM}}$ Excel and by calculating the likelihood of immature and mature individuals as $1 \mathrm{pL}$ and $\mathrm{pL}$, respectively. The reported estimates of the parameters were determined as the median values derived from 200 sets of randomly re-sampled data, with the same sample size, drawn from the data on the observed maturity status at TL for female and male fishes. The $95 \%$ confidence interval was estimated as 2.5 and 97.5 percentiles of the 200 estimates resulting from these re-sampled data (Wood, 2004; White, 2007, Purushottama et al., 2017).

Feeding intensity in various months was analysed for determining the feeding periodicity following Manojkumar et al. (2015) with some modifications. The data on food and feeding habits were combined since no difference was noticed between sexes. The empty stomach ratio (ESR) was also analysed following Rohit et al. (2015).
Based on three indices such as percentage of the wet weight of each food item to the total wet weight of all food items identified $(\% \mathrm{~W})$, percentage of the number of each food item to the total number of all food items identified $(\% \mathrm{~N})$, and frequency of occurrence of each food item in the total number of stomachs examined (\%F) the relative importance of each prey items were identified using Index of relative importance IRI $=(\% N+\% w)$ *\%O (Pinkas et al., 1971; Zacharia and Abdurahiman, 2004). The IRI was expressed as \%IRI to allow for a comparison of the values between the prey groups (Cortes, 1997).

\section{Results and discussion}

The present study provides essential information on the reproductive biology, length at maturity, length-weight relationship and diet of the sparsely studied smooth dwarf monocle bream, $P$. aspinosa found in the Arabian Sea. Commercial trawlers land smooth dwarf monocles as bycatch along Mangaluru, Karnataka region throughout the year, except during the southwest monsoon when no fishing takes place due to rough weather and uniform fishing ban on mechanized gears.

Out of the 827 specimens collected for the study, females constituted $53.6 \%(n=443)$ and males $46.4 \%(n=384)$ with an overall sex-ratio (Male: Female) of 1:1.15. The TL range of females of $P$. aspinosa was $7.4-22.6 \mathrm{~cm} \mathrm{TL}$ (mean \pm S.E $=17 \pm 0.14 \mathrm{~cm}$ ) with weight range of 15.4 $-216 \mathrm{~g}$ (mean \pm S.E $=98.0 \pm 2.3 \mathrm{~g})$. Males ranged from 7.5 $-22.8 \mathrm{~cm}$ TL $($ mean $\pm S . E=16.5 \pm 0.14 \mathrm{~cm})$ and weight ranged from $15-211 \mathrm{~g}$ (mean \pm S.E $=89.0 \pm 2.30 \mathrm{~g}$ ) (Fig. 2). 65 unsexed specimens ranged from $11.1-30.8 \mathrm{~cm}$ $\mathrm{TL}($ mean \pm S.E $=21.0+0.6 \mathrm{~cm}$ ) and weight ranged $29.0-500$ $\mathrm{g}($ mean $\pm S . E=200+15.2 \mathrm{~g})$ was recorded in landing centre. Females were dominant throughout the study period except during November, December, March and April. Results indicated a significant difference $\left(\chi^{2}\right.$-test, $\left.P<0.05\right)$ in overall sex-ratio from the normal 1:1, whereas, month-wise sex ratio recorded as non-significant $(P>0.05)$ except during September and

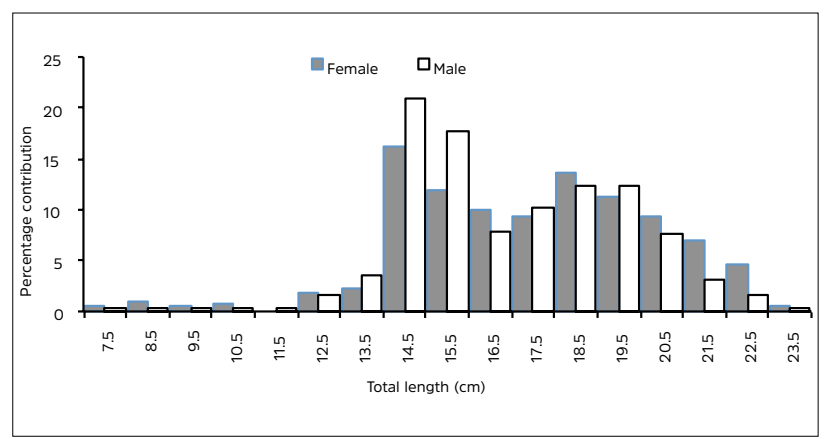

Fig. 2. Total length (TL)- frequency histogram of $P$. aspinosa [ Female $(\square), n=443$; males ( $\square), n=384]$ studied. 
October. It can therefore be inferred that there is no seasonal dominance of a particular sex in $P$. aspinosa occurring in the southwest coast of India. There was also a significant $(P<0.05)$ dominance of females in larger length groups above $18.5 \mathrm{~cm} \mathrm{TL}$, (Table 1 and 2) most due to the migration and differences in growth and behaviour (Nettely et al., 2016). Though $P$. aspinosa is rare in the fishery along the west and east coast of India, its documentation is limited and mostly unreported from many regions. The size range of $P$. aspinosa observed in the trawl net fishery of the Karnataka waters (7.4.0 -30.8 $\mathrm{cm} \mathrm{TL}$ ) differed from those reported from other regions. Naik (2000) examined 511 specimens of both sexes $(9.0-20.5 \mathrm{~cm}$ $\mathrm{TL}$, female $=272$, male $=239)$ in the Goa waters. Karuppasamy et al. (2008) observed 5 specimens of both sexes (16.0-18.0 $\mathrm{cm} \mathrm{TL}$ ) in the eastern Arabian Sea at $120 \mathrm{~m}$ depth. Mohapatra et al. (2013) and Kannan et al. (2013) recorded specimens measuring $10.2 \mathrm{~cm} \mathrm{SL}$ and $14.3 \mathrm{~cm} \mathrm{TL}$, respectively from east coast of India. Furthermore, the present study has recorded the largest TL for $P$. aspinosa $(30.8 \mathrm{~cm} \mathrm{TL}$ ) to date.

Table 1. Length-wise Chi-square $(\chi 2)$ test of sex- ratio of $P$. aspinosa occurring in the coastal waters of Mangaluru, southwest coast of India.

\begin{tabular}{|c|c|c|c|c|c|}
\hline \multirow{2}{*}{ Length-wise Cm (TL) } & \multicolumn{3}{|c|}{ No. of fish } & \multirow{2}{*}{$\begin{array}{l}\text {-Sex- ratio } \\
(\mathrm{M}: \mathrm{F})\end{array}$} & \multirow{2}{*}{$\chi^{2}$} \\
\hline & Total & Male (M) & Female (F) & & \\
\hline $6.5-8.5$ & 8 & 2 & 6 & $1: 3.00$ & 2.00 \\
\hline $8.5-10.5$ & 7 & 2 & 5 & $1: 2.50$ & 1.29 \\
\hline $10.5-12.5$ & 21 & 10 & 11 & $1: 1.10$ & 0.05 \\
\hline $12.5-14.5$ & 243 & 135 & 108 & $1: 0.80$ & 3.00 \\
\hline $14.5-16.5$ & 159 & 74 & 85 & $1: 1.15$ & 0.76 \\
\hline $16.5-18.5$ & 210 & 97 & 113 & $1: 1.17$ & 1.22 \\
\hline $18.5-20.5$ & 129 & 51 & 78 & $1: 1.53$ & $5.651^{*}$ \\
\hline $20.5-22.5$ & 50 & 13 & 37 & $1: 2.85$ & $11.52^{*}$ \\
\hline Pooled & 827 & 384 & 443 & $1: 1.15$ & $4.209^{*}$ \\
\hline
\end{tabular}

*significant differences at $\mathrm{P}<0.05$

Table 2. Monthly Chi-square $(\chi 2)$ test for sex- ratio of $P$. aspinosa

\begin{tabular}{|c|c|c|c|c|c|c|c|c|}
\hline \multirow{2}{*}{ Month } & \multirow{2}{*}{ Total } & \multicolumn{2}{|c|}{ Male (M) } & \multicolumn{2}{|c|}{ Female (F) } & \multirow{2}{*}{$\begin{array}{l}\text { Sex- ratio } \\
\text { (M:F) }\end{array}$} & \multirow{2}{*}{$\chi^{2}$} & \multirow{2}{*}{$P$} \\
\hline & & $n$ & $\%$ & $n$ & $\%$ & & & \\
\hline August 2017 & 127 & 54 & 42.52 & 73 & 57.48 & $1: 1.14$ & 2.843 & 0.09 \\
\hline September & 86 & 32 & 37.21 & 54 & 62.8 & $1: 1.17$ & 5.628 & $0.02^{*}$ \\
\hline October & 97 & 36 & 37.11 & 61 & 62.9 & $1: 1.17$ & 6.443 & $0.01^{*}$ \\
\hline November & 72 & 39 & 54.2 & 33 & 45.83 & $1: 0.8$ & 0.5 & 0.48 \\
\hline December & 65 & 38 & 58.46 & 27 & 41.54 & $1: 0.7$ & 1.862 & 0.17 \\
\hline January 2018 & 79 & 33 & 41.8 & 46 & 58.23 & $1: 1.14$ & 2.139 & 0.14 \\
\hline February & 93 & 41 & 44.1 & 52 & 55.91 & $1: 1.3$ & 1.301 & 0.25 \\
\hline March & 69 & 37 & 53.62 & 32 & 46.4 & $1: 0.9$ & 0.362 & 0.55 \\
\hline April & 76 & 45 & 59.21 & 31 & 40.8 & $1: 0.7$ & 2.579 & 0.11 \\
\hline May & 63 & 29 & 46.03 & 34 & 53.97 & $1: 1.2$ & 0.397 & 0.53 \\
\hline Total & 827 & 384 & 100 & 443 & 100 & $1: 1.15$ & 4.209 & $0.04^{*}$ \\
\hline
\end{tabular}

The weight of $P$. aspinosa ranged between 15.4 to $216 \mathrm{~g}$ in females and between 15.0 to $211 \mathrm{~g}$ in males. The equations relating to total length (TL) and weight (TW) consisting of 443 females (7.4 -22.6 cm TL) and 384 males $(7.5-22.8 \mathrm{~cm} \mathrm{TL})$ are presented below, thus enabling an approximate weight of the smooth dwarf monocle bream to be estimated from a given total length (Fig. 3a, b). The slopes were found to be significantly different between the sexes $(P<0.001)$. The estimated LWR parameters along with the descriptive statistics are given in Table 3.

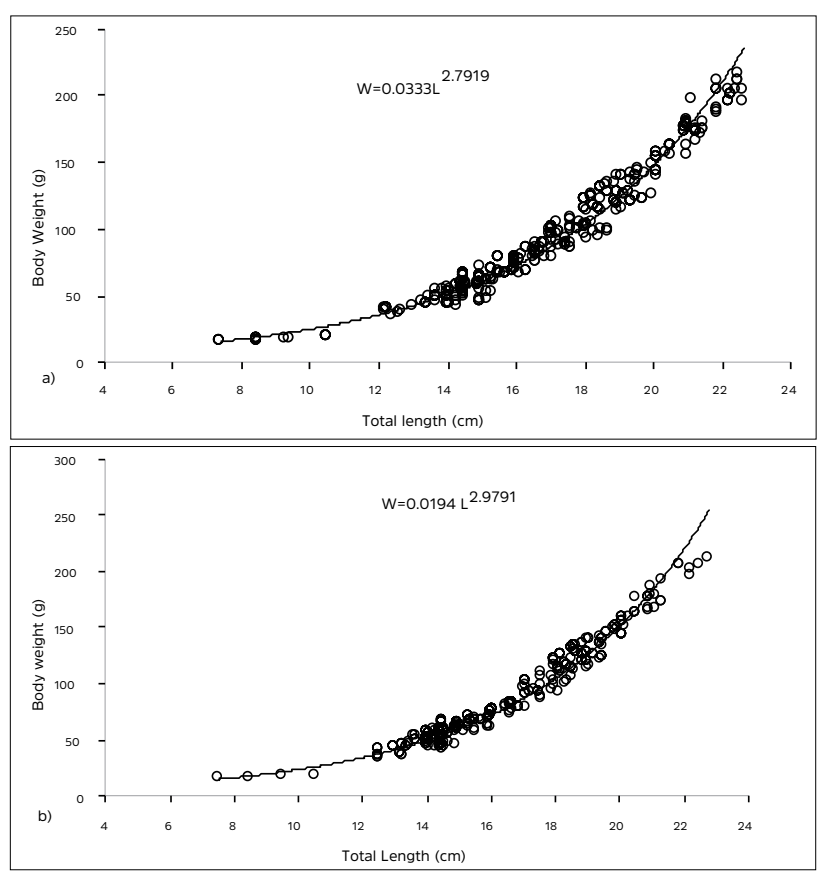

Fig. 3. Length-weight relationship of $P$. aspinosa in the coastal waters of Mangaluru, southwest coast of India. (a) female (b) male.

The parabolic and logarithmic equation for length-weight relationship established for $P$. aspinosa as follows,

Male: $\log W=\log 0.0194+2.9791 \log L\left(W=0.0194 L^{2.9791}\right)$

Female: $\log W=\log 0.0333+2.7919 \log L(W=0.0333$ $\mathrm{L}^{2.7919}$ )

The value of " $b$ " in the length-weight relationship will be " 3 ", if the growth is isometric (Ricker, 1975; Sossoukpe et al., 2013). This cube law relationship is rarely expected, as most of the species change their shape (Hile, 1936). These changes are due to sex, maturity, season and even the time of day due to stomach content (Bagenal, 1978). P. aspinosa in the present investigation exhibits a negative allometric growth pattern (ANCOVA, $p<0.05$ and 0.01 ) at $95 \%$ confidence interval, which implies that the fish grows faster in length than in 
Table 3. Length-Weight Relationships of $P$. aspinosa in the coastal waters of Mangalore, south west coast of India.

\begin{tabular}{|c|c|c|c|c|c|c|c|c|c|c|c|c|}
\hline \multirow{2}{*}{ Sex } & \multirow{2}{*}{$\mathrm{N}$} & \multirow{2}{*}{ TL range $(\mathrm{cm})$} & \multirow{2}{*}{ BW range $(\mathrm{g})$} & \multicolumn{6}{|c|}{ Regression Parameters } & \multicolumn{2}{|c|}{ Student's t-test } & \multirow{2}{*}{$\begin{array}{l}\text { ANCOVA } \\
\text { F-stat (b) / p-value }\end{array}$} \\
\hline & & & & $\mathrm{a}$ & $95 \% \mathrm{CL}$ of a & $\mathrm{b}$ & $95 \% \mathrm{CL}$ of $\mathrm{b}$ & SE (b) & $r^{2}$ & t-stat (b) & $p$-value & \\
\hline$M$ & 384 & $7.5-22.8$ & $15.0-211$ & 0.019 & $0.018-0.020$ & 2.97 & $2.83-3.12$ & 0.033 & 0.96 & 91.2 & $3.5 \mathrm{E}-235^{\star \star}$ & \\
\hline $\mathrm{F}$ & 443 & $7.4-22.6$ & $15.4-216$ & 0.033 & $0.013-0.035$ & 2.79 & $2.65-2.93$ & 0.028 & 0.96 & 100.2 & $2.1 \mathrm{E}-287^{\star \star}$ & $17.9 / 0^{\star \star}$ \\
\hline C & 827 & $7.4-22.8$ & $15.0-211$ & 0.027 & $0.026-0.028$ & 2.86 & $2.71-2.99$ & 0.022 & 0.96 & 131 & $0^{\star \star}$ & \\
\hline
\end{tabular}

$\mathrm{N}$, sample size; $\mathrm{M}$, male; F, female; $\mathrm{C}$, combined sex; TL, total lengths in $\mathrm{cm}$; BW, body weight in g; a and b, parameters of length weight relationship; $\mathrm{CL}$, confidence limits; $\mathrm{SE}$ (b), standard error of slope $b ; r^{2}$, coefficient determination; $t$-stat(b), t-statistic of b; ANCOVA, analysis of covariance; F-stat(b), F-statistic of b; $p$-value, probability level. ${ }^{*} p<0.05 ;{ }^{* *} p<0.01$.

fish body weight. There is no degrees of departure found in slope values ( $t$-statistic, $p>0.05$ and 0.01 ) of both sexes. Naik (2000) reported the coefficients " $a$ ", " $b$ " of the length-weight relationship as $0.017419193,2.973939837\left(r^{2}=0.975\right)$ for females and $0.022494394,2.872986425\left(r^{2}=0.966\right)$ for males. The " $b$ " values found by this author were almost in agreement with the present investigation.

The average $\mathrm{Kn}$ values of each size groups of both the sexes remained low in smaller size classes ranging from 6.5 -7.5 to $9.5-10.5 \mathrm{~cm}$ TL for male and up to 10.5 to $11.5 \mathrm{~cm}$ TL for females. Thereafter a slight difference in condition of fish has been observed in $10.5-11.5 \mathrm{~cm}$ TL size class (0.9957) in case of male, whereas, the Kn values increased progressively up to size class $21.5-22.5 \mathrm{~cm}$ TL size class (1.059). Naik (2000) also reported similar results for $(\mathrm{Kn})$ values among males which ranged from 0.97457 to 1.14932 in males 0.977624 to 1.0616812 in females. Highest $\mathrm{Kn}$ values were recorded for males of $19.0-19.9 \mathrm{~cm}$ TL length class. In most of the sizes, the males had higher $\mathrm{Kn}$ values than females. The values of Kn decreased from smaller to larger fishes of about 130-139 mm size class, whereas the $\mathrm{Kn}$ values increased as they grew further. This trend was noticed up to the biggest size recorded.

Under microscopic observation of ova, seven stages of maturity could be identified. In stage I, the size of the ova ranged from $0.064 \mathrm{~mm}$ to $0.144 \mathrm{~mm}$ (mode of 4 OMD; $0.064 \mathrm{~mm}$ ) which shifted to 0.064 to $0.096 \mathrm{~mm}$ in stage II with a maximum size of the ova at $10 \mathrm{OMD}(0.160 \mathrm{~mm})$. During progressive maturation of gonads to stage III $(0.24 \mathrm{~mm}$ to $0.304 \mathrm{~mm})$,

Table 4. Progression of ova diameter in advanced maturity stages in $P$. aspinosa

\begin{tabular}{llll}
\hline $\begin{array}{l}\text { Stages of } \\
\text { maturity }\end{array}$ & Description of ova & $\begin{array}{l}\text { Mode of largest group } \\
\text { of ova }(\mathrm{mm})\end{array}$ & $\begin{array}{l}\text { Maximum size of ova } \\
(\mathrm{mm})\end{array}$ \\
\hline I & Immature & 0.064 & 0.144 \\
\hline II & Maturing virgin & 0.096 & 0.16 \\
\hline III & Early mature & 0.192 & 0.304 \\
\hline IV & Late mature & 0.368 & 0.48 \\
\hline $\mathrm{V}$ & Matured & 0.624 & 0.864 \\
\hline $\mathrm{VI}$ & Ripe & 0.848 & 1.008 \\
\hline $\mathrm{VII}$ & Spent & 0.096 & 0.192 \\
\hline
\end{tabular}

opaque ova started to appear. At this stage, the ova of 12 OMD $(0.192 \mathrm{~mm})$ were found to be numerous and the maximum size of ova was $0.304 \mathrm{~mm}$. At stage IV, opaque ova were predominant, the mode of the largest size of ova being $23 \mathrm{OMD}(0.368 \mathrm{~mm})$ and the maximum size attained were $30 \mathrm{OMD}$ or $0.48 \mathrm{~mm}$. As the ovary reaches stage $\mathrm{V}$, ova becomes larger with mode at $0.39 \mathrm{~mm}$ and the maximum size of 54 OMD $(0.864 \mathrm{~mm})$. At stage $\mathrm{VI}$, the mode was at $0.864 \mathrm{~mm}$, with maximum size attained as 63 OMD (1.008 $\mathrm{mm}$ ). At stage VII (spent), the size of the ova resembles the immature stages (Table 4).

In the case of males, differentiation of male maturity stages was found to be difficult due to the tiny appearance of the testis, similar to the observations made by Nettely et al. (2016) in Nemipterid fishes from coastal waters of Bintulu, South China Sea. High GSI values were observed during August-September, and January for both sexes (Fig. 4), which subsequently declined in the following months. GSI values were significantly different between months for females (ANCOVA, $F=34.01$, d.f. $=9.422, P<0.05$ ) and males (ANCOVA, $F=10.99$, d.f. $=9.359, \mathrm{P}<0.05)$. Month-wise percentage occurrence of mature gonads followed similar trend for both sexes. The maximum percentage of mature gonads were recorded during September, January and February, which is in concurrence with the GSI values suggesting that $P$. aspinosa breeds throughout the year. This is similar to the generic observations by Baragi and James (1980), that mature fishes occurs throughout the year in most tropical marine fishes as maturation is a continuous

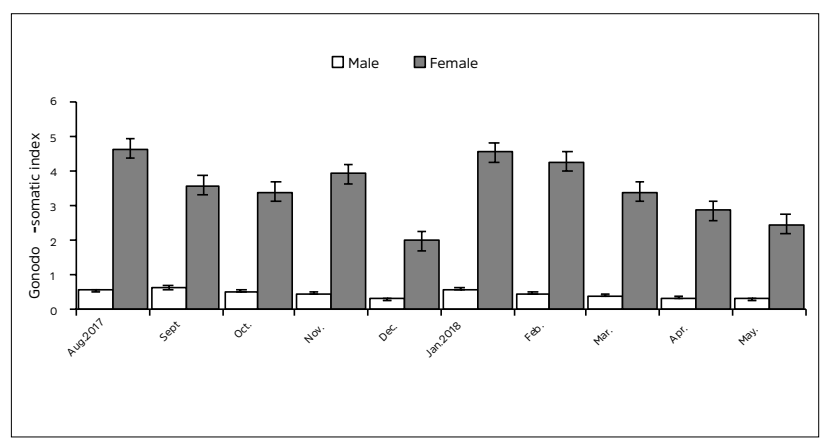

Fig. 4. Month-wise GSI values of female (ANOVA, $F=34.01$, d.f. $=9.422, P<0.05$ ) and males (ANOVA, $F=10.99$, d.f. $=9.359$, $P<0.05)$ of $P$. aspinosa occurring in the coastal waters of Mangaluru, southwest coast of India (Bars indicate \pm standard error). 
process. Naik (2000) also observed increased GSI values from September to January for $P$. aspinosa. In nemipterids, the GSI of $N$. randalli (= N.mesoprion) increased from August to peak during October-November, decreased during January and increased again in later months. However as per Naik, (2000), increase in GSI for $N$. japonicus begins from postmonsoon months, peaking during December-January. GSI values remained highest during the peak spawning of fishes in Indian waters (Pillay, 1958).

The length at maturity $\left(\mathrm{TL}_{50}\right)$ determined in the present study was $12.5 \mathrm{~cm}$ TL for females and and $11.5 \mathrm{~cm}$ TL for males of P. aspinosa (Fig. 5a \& 5b). However, the observation made by Naik (2000) indicated $\mathrm{TL}_{50}$ of females as $11.6 \mathrm{~cm}$ TL and 11.8 $\mathrm{cm}$ TL for males in Goa, west coast of India. It can be concluded from the present study that both sexes of $P$. aspinosa matures at length range of $11.0 \mathrm{~cm}-13.0 \mathrm{~cm} \mathrm{TL}$. The fecundity ranged from 45,823 to $1,56,308$ eggs with an average of 84,367 eggs. The number of ova increased proportionally with increase in length, weight as well as gonad weight of the fish. The correlation analysis of log fecundity and total length $(Y=1.7806+2.5129$ $X, r=0.97)$, body weight $(Y=3.4488+1.2162 X, r=0.93)$ and gonadal weight $(\mathrm{Y}=3.4015+1.6555 \mathrm{X}, \mathrm{r}=0.91)$ of $P$. aspinosa was arrived at as perfect linear correlation.

P. aspinosa is a carnivorous bottom-feeding fish with preference for the major groups of preys: i) crustaceans ii) fishes iii)
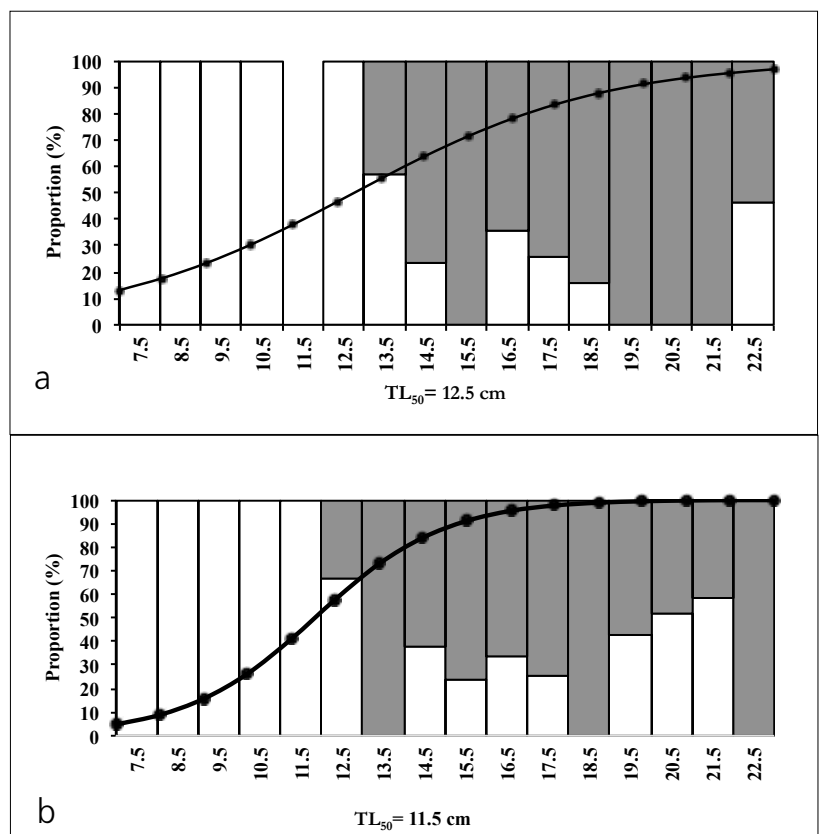

Fig. 5. Percentage frequency of occurrence of immature ( $\square$ ) and mature (घ) P. aspinosa in sequential total length (TL) classes for (a) females and (b) males. Numbers above each bar represent the sample size in each sequential TL class. Arrows indicate the TL at which $50 \%$ of females and males attain maturity $\left(\mathrm{TL}_{50}\right)$. cephalopods. Among fishes, Saurida spp., Stolephorus spp., Nemipterus spp. were recorded. Squilla, Penaeus indicus, Acetes spp. were accounted among crustaceans and Loligo spp. were frequently recorded under cephalopods. Analysis of the stomach contents (\%IRI) revealed that $P$. aspinosa fed primarily on crustaceans ( $48.3 \%)$, followed by teleosts (35.2\%) and cephalopods (16.5\%). Naik (2000) suggested that food of this deep-water species is predominantly formed by crustaceans, as in the case of other nemipterids. Existence of a wide range of crustaceans in the stomach of $N$. japonicus has been reported by earlier workers (Kuthalingam, 1965; Krishnamoorthi, 1971; Karuppasamy et al., 2008; Afshari et al., 2013; Manojkumar et al., 2015).

Percentage of relative importance (IRI) values were Saurida tumbil $(\% \mathrm{IRI}=18.2)$, P. indicus (\% $\mathrm{RI}=16.7)$, Loligo spp., $(\% \mid R I=15.2)$, Squilla $(\% \mid R I=6.4)$ and Acetes spp. $(\% \mid R I=2.7)$ for prey items recognized in the study and unidentified crustaceans accounts $\% \mid R I=22.4$, and unidentified fishes $(\% \mathrm{IRI}=16.7)$ contributed significantly in the diet of $P$. aspinosa. Smaller quantities of other prey items includes Nemipterus spp. and Stolephorus spp. (\%IRI=0.3 each) (Table 5). In this study, it was observed that juvenile fishes feed mainly on crustaceans, whereas, larger individuals feed mainly on

Table 5. Prey composition of $P$. aspinosa from Mangaluru, southwest coast of India

\begin{tabular}{llllll}
\hline Prey item & $\% \mathrm{~N}$ & $\% \mathrm{~W}$ & $\% 0$ & $\mid \mathrm{RI}$ & $\% \mid \mathrm{RI}$ \\
\hline Crustaceans & & & & & \\
\hline Acetes spp. & 6.8 & 5.1 & 6.2 & 74 & 2.7 \\
\hline Penaeus indicus & 15.3 & 17.6 & 13.9 & 458.9 & 16.7 \\
\hline Squilla & 9.6 & 9.2 & 9.4 & 176.1 & 6.4 \\
\hline Other unidentified shrimp & 15.9 & 16.3 & 19.1 & 614.8 & 22.4 \\
\hline Cephalopods & & & & & \\
\hline Loligo spp. & 15.3 & 13.4 & 14.6 & 417.8 & 15.2 \\
\hline Other Unidentified Cephalopods & 5.1 & 4 & 4 & 36 & 1.3 \\
\hline Teleost fishes & & & & & \\
\hline Saurida tumbil & 14.8 & 17.7 & 15.4 & 499.9 & 18.2 \\
\hline Stolephorus spp. & 2.3 & 3 & 1.5 & 7.7 & 0.3 \\
\hline Nemipterus spp. & 1.4 & 2.4 & 2 & 7.5 & 0.3 \\
\hline Other Unidentified fish & 14.9 & 13.7 & 16 & 457.8 & 16.7 \\
\hline
\end{tabular}

teleost fishes which denotes increased piscivorous feeding habits with increase in age of these fishes.

Out of 827 species examined during the study period, 201 stomachs were full $(29 \%), 102$ were $3 / 4^{\text {th }}$ full $(13 \%)$, 78 were $1 / 2^{\text {th }}$ full $(9 \%), 139$ were $1 / 4^{\text {th }}$ full $(15 \%)$ and 307 were found empty (34\%) (Fig.6). The high occurrence of empty stomachs may be due to several reasons: absence of favourite food item, condition of the fish or eviction of gut contents during 


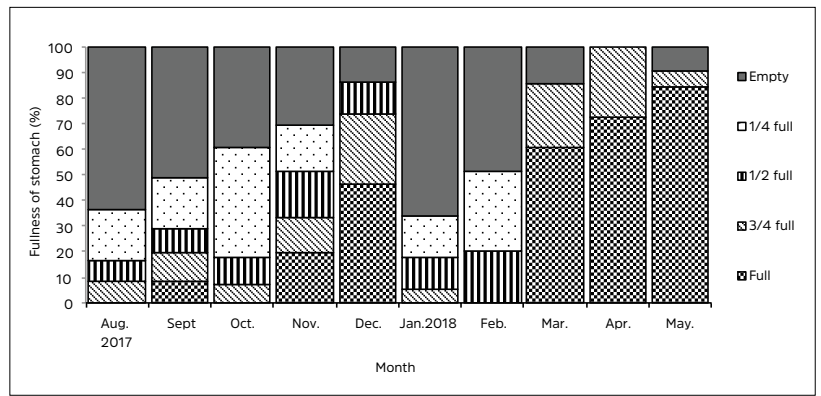

Fig.6. Feeding frequency of $P$. aspinosa in the coastal waters of Mangaluru, southwest coast of India.

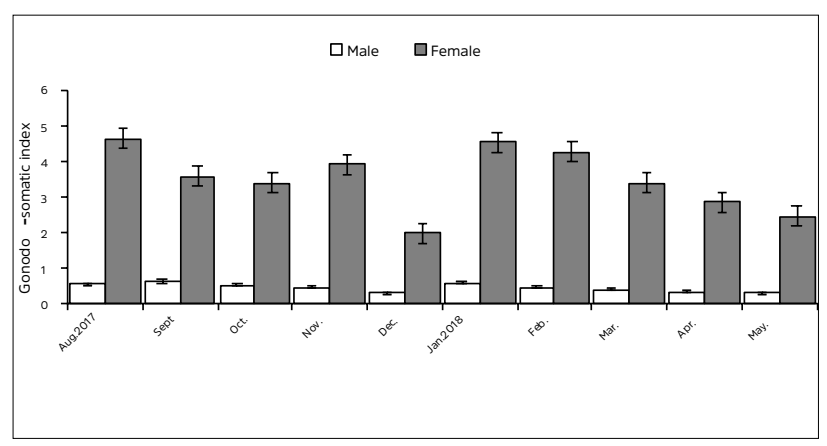

Fig.7. Monthly variation in the Empty Stomach Ratio (\%ESR) of $P$. aspinosa

trawl catch or the food might have digested completely and caught before subsequent feeding. ESR values were found higher during August-September and January-February, which can be related with the peak spawning season of these fishes (Fig.7). Naik (2000) suggested that presence of more number of empty stomachs may be mostly due to overcrowding and struggling of fishes while the net was dragged through the bottom and to lesser extent due to the act of pressure and weight on the abdomen when the net is hauled up. It is also mentioned that, proper identification of the gut contents is possible only when there is short gap between feeding and capture and by adaptation of proper execution methods for analysis of gut contents.

The present study deals with fishery biology of $P$. aspinosa along Karnataka coast. This fish is not popular among fish eating community of the state and formed very low percentage among nemipterid catches during the last decade of $21^{\text {st }}$ century. Absence of biological studies hinders in making any assessment or management recommendations along southwest coast of India. Therefore, the present investigation becomes significant as it will help to fill the knowledge-gap on the size distribution, length-weight relationship, maturation and spawning and diet of $P$. aspinosa from Karnataka waters in eastern Arabian Sea. Understanding critical aspects of biology is a prerequisite for sustainable management of harvests and this is particularly important for species such as $P$. aspinosa that are considered as potential candidates for the commercial fishery in the future.

\section{Acknowledgements}

The authors express their sincere gratitude to the Dean and staff of the College of Fisheries, Mangalore and the Scientist in-Charge and staff of Mangalore Regional Centre of CMFRI, Mangaluru for providing necessary facilities and support.

\section{References}

Afshari, M., T. Valinassab, J. Seifabadi and E. Kamaly. 2013. Age determination and feeding habits of Nemipterus japonicus (Bloch,1791) in the Northern Oman Sea. Iran. J. Fish. Sci., 12 (2): 248-264.

Bagenal, T. B. 1978. Methods for Assessment for Fish Production in Freshwater, $3^{\text {rd }}$ ed. Blackwell Scientific Publication, London.

Baragi, M. V. and P. S. R. B. James. 1980. Reproductive biology of Sciaenid Fish Johnieops osseus (Day) from the South Kanara Coast. Indian J. Mar. Sci., 9 (1): 19-24.

CMFRI 2017. Annual report 2015-16. Central Marine Fisheries Research Institute, Cochin, $292 \mathrm{pp}$.

Cochran, W. G. 1952. The $\chi 2$ test of goodness of fit. Ann. Math. Stat., 25: 315-345.

Cortés, E. 1997. A critical review of methods of studying fish feeding based on analysis of stomach contents: application to elasmobranch fishes. Can. J. Fish and Aquat. Sci., 54:726 -738.

Dineshbabu, A. P., Sujitha Thomas and S. Shailaja. 2017. Efficacy of spatial study on catch and effort from fishing vessels for strengthening fisheries management. J. Mar. Biol. Ass. India, 59(1): 31-35.

Ellis, J. R. and S. E. Shackley. 1997. The reproductive biology of Scyliorhinus canicula in the Bristol Channel, U. K. J. Fish Biol., 51(2): 361-372.

Froese, R. 2006. Cube law, condition factor and weight-length relationships: History, meta- analysis and recommendations. J. App. Ichthyol., 22: 241-253.

Hile, R. 1936. Age and growth of Siscoleucichthys arteli (Lesueur) in Lake of Three Northern Highlands, Wisconsin. Bull. U.S. Bur. Fish., 48: 209-317.

Joshi, K. K. 2005. Biology and population dynamics of Nemipterus mesoprion (Bleeker) off Cochin. Indian J. Fish., 52(3): 315-322.

Kannan, K., L. Ranjith, K. Sureshkumar, S. Mohamed Sathakkathullah, K. John James and M. S. Madan. 2013. Occurrence of Parascolopsis eriomma (Jordan and Richardson, 1909) and P. aspinosa (Rao \& Rao, 1981) from Tuticorin coast. Mar. Fish. Infor. Serv. T\&E Ser., 217: 23-24.

Karuppasamy, P. K., K. Balachandran, S. George, S. Balu, V. Persis and N. G. Menon. 2008. Food of some deep sea fishes collected from the eastern Arabian Sea. J. Mar. Biol. Ass. India, 50(2): 134 - 138.

Kerdgari, T., S. Valinassab, M. Jamili, R. Fatemi and F. Kaymaram. 2009. Reproductive biology of the Japanese threadfin bream, Nemipterus japonicus, in the Northern Perisan Gulf. J. Fish. Aquat. Sci., 4(3): 143-149.

Krishnamoorthi, B. 1971. Biology of the threadfin bream, Nemipterus japonicus (Bloch, 1791). Indian J. Fish., 18(1-2): 1-21.

Kuthalingam, M. D. K. 1965. Notes on some aspect of the fishery and biology of Nemipterus japonicus (Bloch, 1791) with special reference to feeding behaviour. Indian J. Fish., 12(2A): 500-506.

Le Cren, E. D. 1951. The length-weight relationship and seasonal cycle in the gonad weight and condition in the perch (Perca fluviatilis). J. Anim. Ecol., 20: 201-219.

Lovern, J. A. and H. Wood. 1937. Variations in the biochemical composition of herring. J. Mar. Biol. Assoc. U.K., 22: 281-293.

Manojkumar, P. P. 2004. Some aspects on the biology of Nemipterus japonicus (Bloch) from Veraval in Gujarat. Indian J. Fish., 51(2): 185-191.

Manojkumar, P. P. 2015. Food and feeding habits of Nemipterus japonicus (Bloch) from Malabar coast, Kerala. Indian J. Fish., 62(1): 64-69.

Mohapatra, A., P. C. Tudu, D. Ray and P. Yennawar. 2013. First report on the occurrence of four fishes of family: Nemipteridae from Digha on the east coast of India. Rec. Zool. Surv. India, 113(Part-1): 145-149.

Montgomery, D. C., E. A. Peck and G. G. Vining. 2012. Introduction to Linear Regression Analysis, (Wiley publication, New Jersey), 152 pp.

Naik, S. K. 2000. Some studies on the biology of Nemipterids of Goa coast. Ph. D. Thesis, Goa University, Taleigao Plateau, Goa, India, 177 pp.

Nettely, A. H., N. A. Rajaee, M. H. Denil, M. H. Idris, S. M. Nesarul, N. Amin and M. K. A. Hena. 2016. Reproductive biology of Nemipterus japonicus (Bloch, 1791) from the coastal waters of Bintulu (South China Sea), Sarawak, Malaysia. J. Environ. Biol., 37: 715-724. 
Pillay, T. V. R. 1958. Biology of the hilsa Hilsa ilisha (Ham.) of the river Hooghly. Indian J. Fish., 5: 201-259.

Pinkas, L., M. S. Oliphant and I. L. K. Iverson. 1971. Food habits of albacore, bluefin tuna, and bonito in California waters. Cal. Fish Game, 152: 1-105.

Purushottama, G. B., Thakurdas., V. Ramasubramanian, D. Gyanaranjan, K. V. Akhilesh, S. Ramkumar, S. J. Kizhakudan, V. V. Singh and P. U. Zacharia. 2017. Reproductive biology and diet of grey sharpnose shark Rhizoprionodon oligolinx Springer, 1964 (Chondrichthyes: Carcharhinidae) from the northeastern Arabian Sea. Indian J. Fish., 64(4):9-20.

Rao, D. M. and K. S. Rao. 1981. A revision of the genus Scolopsis cuvier (Pisces: Nemipteridae) with descriptions of two new species from Indian waters. Proc. $K$. Ned. Akad. Wet. C., 84(1): 131-141.

Ricker, W. E. 1975. Computer and interpretation of biological statistics of fish population. Bull. Res. Board Can., p. 315-318.

Rohit, P., K. M. Rajesh, G. Sampath Kumar and K. Sahib. 2015. Food and feeding of the ribbonfish Trichiurus lepturus Linnaeus off Karnataka, south-west coast of India. Indian J. Fish., 62(1): 58-63.

Russell, B. C. 1990. FAO Species Catalogue. Nemipterid fishes of the world. (Threadfin breams, whiptail breams, monocle breams, dwarf monocle breams, and coral breams). Family Nemipteridae. An annotated and illustrated catalogue of nemipterid species known to date. FAO Fish. Synop., 125(12):149 pp. FAO, Rome.

Russell, B. C. and D. Golani. 1993. A review of the fish genus Parascolopsis (Nemipteridae) of the Western Indian Ocean, with description of a new species from the northern Red Sea. Israel. J. Zool., 39: 337-347.
Shapiro, S. S. and M. B. Wilk. 1965. An analysis of variance test for normality (complete samples), Biometrika, 52(3 \& 4): 591-611.

Snedecor, G. W. and W. G. Cochran. 1967. Statistical methods, 6th Edn. Oxford and IBH Publishing Co., New Delhi, India.

Sossoukpe, E., F. K. E. Nunoo, P. K. Ofori-Danson, E. D. Fiogbe and H. R. Dankwa. 2013. Growth and mortality parameters of Parascolopsis senegalensis and Parascolopsis typus (Sciaenidae) in nearshore waters of Benin (West Africa) and their implications for management and conservation. Fish. Res., 137:71- 80.

White, W. T. 2007. Catch composition and reproductive biology of whaler sharks (Carcharhiniformes: Carcharhinidae) caught by fisheries in Indonesia. J. Fish Biol., 71(5): 1512-1540.

Wood, M. 2004. Statistical inference using bootstrap confidence intervals. Significance, 1: $180-182$

Zacharia, P. U. and G. D. Nataraja. 2003. Fishery and biology of threadfin bream, Nemipterus mesoprion from Mangalore-Malpe. Indian J. Fish., 50(1): 1-10.

Zacharia, P. U. and K. P. Abdurahiman. 2004. Methods of stomach content analysis of fishes. In: Winter School on Towards Ecosystem Based Management of Marine Fisheries-Building Mass Balance Trophic and Simulation Models (Mohammed, K.S., ed.), p. 148-158. 